\title{
Let us stop regulating DNA research
}

The Royal Society critique (Nature, 15 February 1979, page 510) of the proposed new approach by Britain's Genetic Manipulation Advisory Group (Nature, 9 November 1978, page 102) to recombinant DNA regulation is correct on at least one point. We do not have the facts on hand to make the quantitative risk assessments to decide whether a proposed experiment should be done under maximal, minimal, or no precautions.

Assigning numbers in the manner suggested by Dr Sydney Brenner implies that we have some real measure of prospective risk. However, to my knowledge there is no evidence that any prospective recombinant DNA experiment poses any realistic threat to any scientist who uses the tools of his trade, much less to society itself. I thus do not see any logical way to arrive at such numerical risks, and the whole GMAG exercise strikes me as having no more validity than quantitative religion.

To be sure some experiments like putting $E$. coli genes back into $E$. coli are thought safe by virtually all informed individuals. In contrast, the insertion of the gene for the botulinus toxin into $E$. coli might strike some competent scientists as risky. But how much additional peril will be generated beyond that involved with working with botulinus organism itself is not obvious.

The a priori guesses that different knowledgeable minds will give may at best tell us something about their respective neuroses or lack of them. Each of us has different thresholds of fear, be it rational or irrational. For my part, I already see so many unambiguous hazards, like dioxin, that I remain incapable of adding still one more unless I see some real numbers. Recombinant-DNA-induced diselases to me fall in the category of UFOs or witches. Others may take

\section{By J. D. Watson}

them seriously, but they should not expect me to join in. I would not spend a penny trying to see if they exist and would regard as pure folly the decision to spend sizable sums of money on such projects.

I am thus appalled by the recent proposals of the Honourable Joseph Califano and Shirley Williams that their respective governmental departments (HEW and the Department of Education and Science) initiate extensive experiments to probe the presumptive safety of recombinant DNA experiments. The variety of prospective experiments is so legion that we have no possibility of checking even a tiny fraction for their potential danger.

\section{'Recombinant-DNA-induced diseases, to me, fall in the category of UFOs or witches'}

Moreover, the answers we could obtain would have no real carry-over to other even closely related situations. So we would be spending vast sums of money (Shirley Williams has proposed tens of million pounds) merely to give the facade of responsibility. In fact, we would be irresponsible by diverting money away from projects which unambiguously might advance science, if not society itself.

We must thus be careful not to undertake risk assessment experiments merely because they can be done. Here I part company with the Royal Society's position that we should see, for example, whether nonpathogenic strains of $E$. coli can be converted into pathogens through random insertion of foreign DNA. Such data are very unlikely to affect the way we work with recombinant DNA. Unless we directly take DNA from pathogenic bacteria, the chances of a positive answer are low. But even if we were to generate a new pathogen, it is not obvious that it would pose any special risk.

Almost totally lacking in the past six years of seemingly never-ending conjectures about the dangers from recombinant DNA experimentation is recognition of the fact that the world is already filled with large varieties of pathogenic microorganisms of many types. Moreover, they are constantly mutating to give us new forms that we have not seen before. Some are constantly making us ill, and sometimes even doing us in. For the most part, however, we can fight them at least to a draw, and, of necessity, most of us do not spend much time worrying whather the next time they will get us. Otherwise we would be completely paralysed from any constructive behaviour.

Instead of continuing to waste masses of paper and the time of countless individuals who have real jobs to carry out, I believe we should quickly and resolutely abandon any form of recombinant DNA regulation. Concurrently our national leaders should announce that they will help push DNA research as fast as our national and corporate treasuries can permit.

At the same time we should, of course, remain alert to the rare possibility that one or more recombinant DNA research workers will come down with a disease we have not seen before. If that happens we naturally would have a story that deserves serious journalism, and for the first time there would be real facts for the risk assessor. But until that situation arises, and I'm doubtful that it ever will, we must make clear to the public that there is no more reason to fear recombinant DNA than there is to panic about the Loch Ness Monster. if wave power is to be competitive with the estimated $1 \mathrm{p}-2 \mathrm{p}$ per $\mathrm{kwh}$ cost of windpower and with the standard fossil fuel costs of $1 \frac{1}{2} p$ per $k w h$.

American Institute of Physics wins tax exemption: The American Institute of Physics, the umbrella organisation for nine separate physics societies, has won its appeal against a tax ruling that would have deprived it of tax exempt status.

Many of the institute's activities, including the publication of a number of journals, had been placed in jeopardy by a decision taken last year by the Manhattan District Office of the Internal Revenue Service that it was not entitled to tax exemption as a scientific, educational and charitable organisation.

The institute filed a protest in December against this ruling, which is thought to have been made on the grounds that the institution provides a specialist service to its member societies which is not available to the general public.

In a letter received by the institute last week, the national office of the IRS said that it had considered the institute's appeal, and had decided in its favour. "The entire physics community will be pleased with the Internal Revenue Service ruling", said Professor Philip Morse, chairman of the AIP's governing board. 